\title{
Unusual shallow water Devonian coral community from Queensland and its recent analogues from the inshore Great Barrier Reef
}

\author{
Mikołaj K. Zapalski ${ }^{1}$ (D) Andrew H. Baird ${ }^{2}$ - Tom Bridge ${ }^{2,3} \cdot$ Michał Jakubowicz $^{4}$ (I) \\ James Daniell ${ }^{5}$
}

Received: 7 June 2020/ Accepted: 23 December 2020/Published online: 4 February 2021

(C) The Author(s) 2021

\begin{abstract}
Palaeozoic coral communities were dominated by two extinct coral groups: Tabulata and Rugosa. Whilst they are not closely related to modern Scleractinia, they are morphologically convergent, displaying many morphological characters that allow comparisons between recent and ancient coral reef communities. The extensive shallowwater reef communities of the Devonian were generally dominated by stromatoporoid sponges, with corals occupying deeper environments. Here, we describe an unusual, shallow water coral reef community from the Middle Devonian (Givetian, approx. $385 \mathrm{Ma}$ ) of the Fanning River area, Queensland, Australia. The coral community is dominated by tabulate corals, but also includes solitary and occasionally colonial rugose corals. Tabulate corals most commonly exhibit foliose and massive morphologies, but
\end{abstract}

Topic Editor Steve Vollmer

Supplementary Information The online version contains supplementary material available at (https://doi.org/10.1007/s00338020-02048-9).

Mikołaj K. Zapalski

m.zapalski@uw.edu.pl

1 Faculty of Geology, University of Warsaw, Żwirki i Wigury 93, 02-089 Warszawa, Poland

2 ARC Centre of Excellence for Coral Reef Studies, James Cook University, Townsville, QLD 4811, Australia

3 Biodiversity and Geosciences Program, Museum of Tropical Queensland, Queensland Museum Network, Townsville, QLD 4810, Australia

4 Isotope Research Unit, Adam Mickiewicz University, Krygowskiego 10, 61-680 Poznań, Poland

5 College of Science and Engineering, James Cook University, Townsville 4811, Australia encrusting and branching growth forms also occur. The depositional environment was characterized by a shallow water depth, moderate hydrodynamic energy, high sedimentation rate, and high turbidity. Since these environmental factors influence the morphological composition of modern coral communities, we hypothesize that similar environments may result in morphologically equivalent coral assemblages throughout the Phanerozoic. To test this idea, we qualitatively compare the Fanning River reefs with modern scleractinian coral assemblages in a similar environmental setting at Magnetic Island. Both reefs are located in a shallow water less than $10 \mathrm{~m}$ deep, with high sediment flux, moderate wave energy, and generally high turbidity. Like Fanning River, Magnetic Island coral communities are dominated by foliose morphologies, with contributions from massive and branching forms. The Fanning River reef, together with previously identified Silurian and Devonian mesophotic coral ecosystems, suggest that Palaeozoic coral assemblages may share many functional characteristics with modern scleractinian reefs in similar environments. Therefore, the geological record of inshore, high turbidity-adapted coral communities can be traced back as far as 385 Ma.

Keywords Tabulata $\cdot$ Givetian · Gondwana $\cdot$ Actualism . varcus

\section{Introduction}

The Silurian and Devonian periods of the Palaeozoic are characterized by extensive reef development (Copper 2002a). The palaeogeographic configuration of the continents combined with vast shelf seas in the tropical zone facilitated the development of coral-stromatoporoid reefs 
that covered significantly larger portions of the seafloor than reefs in modern seas (Copper and Scotese 2003). Some reefs exceeded the size of the modern Great Barrier Reef, such as the reef belt extending from Nevada to Ellesmere Island that spanned $5000 \mathrm{~km}$ (Copper 2002a). The peak of reef development occurred during the Givetian stage ( 387-382 Ma) of the Middle Devonian (Burchette 1981; Fagerstrom 1994; Kiessling 2008). These spectacular reefs collapsed during the Late Devonian Frasnian-Famennian extinction event $(\sim 372 \mathrm{Ma})$, after which metazoan-dominated reef communities were replaced by microbial-dominated communities (e.g. Wood 1999; Copper 2002b, 2011; McGhee et al. 2012). The collapse of these reefs was possibly a consequence of rising temperatures and associated widespread bleaching of shallow-water corals (Zapalski et al. 2017a). Mid-Palaeozoic bioconstructing communities were dominated by a group of hypercalcifying sponges called stromatoporoids (Kershaw et al. 2018), with significant contributions from two extinct groups of corals: Tabulata and Rugosa (subclasses within Anthozoa, Hill 1981), which in certain environments outnumbered stromatoporoids. Neither are directly related to modern corals, and their evolutionary lineages most probably diverged in the early Palaeozoic (Scrutton 1997; Quattrini et al. 2020).

The morphology of corals is influenced by both genetic and environmental factors. Amongst the latter, the most important are light availability, water hydrodynamics and sedimentation rate (e.g. Rogers 1990; Kaandorp 1999; Todd 2008). Despite taxonomic differences, Palaeozoic corals share many morphological characters that allow functional comparisons between recent and ancient coral communities. Such morpho-functional convergences between Palaeozoic rugose and tabulate and Recent scleractinian corals have enabled identification of mesophotic coral ecosystems (MCEs) from the Silurian (ca. $430 \mathrm{Ma}$ ) of Sweden (Zapalski and Berkowski 2019) and the Devonian (ca. $390 \mathrm{Ma}$ ) of Poland (Zapalski et al. 2017b). Like modern MCEs, these communities were dominated by platy and foliose corals and developed in relatively deep water environments. Platy morphology in modern scleractinian corals is uniquely associated with photosymbiosis (e.g. Graus and Macintyre 1976; Anthony and HoeghGuldberg 2003; Kahng et al. 2012); therefore, platy morphology suggests that these Palaeozoic corals were also photosymbiotic. Other skeletal features, such as the corallite size, growth rate and level of colony integration, enable comparisons between Palaeozoic corals and extant zooxanthellate scleractinians (Coates and Jackson 1987; Zapalski 2014; Zapalski et al. 2017a).

Amongst the Middle Palaeozoic reefs, the Givetian coral-stromatoporoid communities are of particular interest for palaeoecological studies. They occurred in diverse environments, including both shallow-water settings and deeper shelves (e.g. Tsien et al. 1980; Zapalski et al. 2017b; Jakubowicz et al. 2019). These communities formed bioconstructions that are equivalent to modern reefs, including fringing, barrier and patch reefs, as well as atolls (Klovan 1974; Playford 1980; Burchette 1981; Racki 1992; Gischler 1995; Shen et al. 2008). Sedimentological and paleoenvironmental data indicate that the shallowest of these reefs developed above the fair-weather wave-base and were dominated by stromatoporoid sponges, whilst corals, especially tabulates, were usually restricted to deeper-water environments (e.g. Lecompte 1958; Embry and Klovan 1972; Scrutton 1998; Jakubowicz et al. 2019). Consequently, very shallow, inshore coral communities of this age are relatively rare and, therefore, poorly known.

In modern reef environments, platy and foliose coral species are the most characteristic of deeper water or shallow, sheltered environments with high turbidity and low ambient light (e.g. Riegl et al. 1996; Hallock 2005), although other colony morphologies also occur. Platy morphologies are advantageous in low light because they maximize surface area available to harvest ambient light (and therefore photosynthetic active radiation [PAR]) to support photosynthesis (Anthony et al. 2005; Kahng et al. 2012). Therefore, coral communities dominated by platy/foliose forms (together with other morphological forms of coral colonies) are common in Recent high-turbidity environments, such as reefs on landward rim of high islands on the inshore Great Barrier Reef (Bull 1982; Veron 1995).

Here, we describe an unusual, inshore coral reef community from the Givetian ( $\sim 385 \mathrm{Ma})$ of the Fanning River area (Burdekin River Basin, Queensland, Fig. 1a), dominated by platy and massive tabulate corals. Palaeoenvironmental data show that the reef (understood in the broadest sense) growth took place in a very shallow $(<10 \mathrm{~m})$, turbid environment, with substantial clastic input due to its proximity to exposed, granitoidic hinterland and nearby river mouths (Cook 1994; Zhen 1996).

If the morphology of the coral colony is to a certain extent controlled by the environment, then coral communities could develop similar functional composition in similar environmental settings regardless of their taxonomic identity (e.g. Kaandorp 1999; Anthony and HoeghGuldberg 2003). Here, we compare the morphological composition of a modern inshore coral community comprising scleractinian corals (Magnetic Island, Fig. 1b) to the fossil assemblage in a similar environment at Fanning River. Both communities grow on shallow fringing reefs in a turbid environment with sediment input from nearby rivers and also from weathering of granitoidic headlands (Morrissey 1980; Larcombe et al. 1995; Lewis et al. 2012). We analyse the composition of both coral communities and 


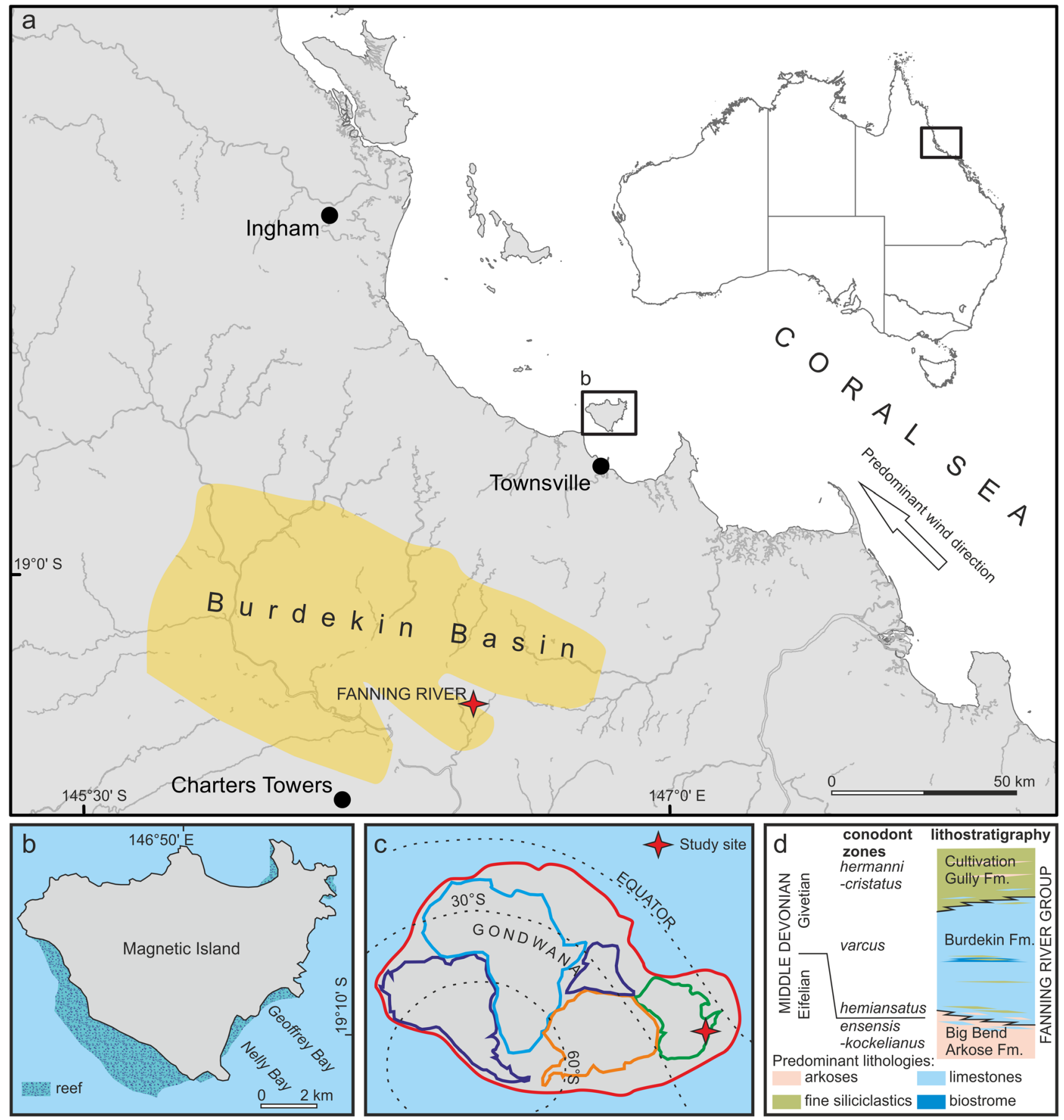

Fig. 1 Maps showing the study site. a. in the Townsville hinterland and within Australia (after Zhen 1991; guesstimate of the Devonian Burdekin Basin after Talent and Mawson 1994); b. Magnetic Island, location of Geoffrey and Nelly Bay reefs, based upon the Great Barrier Reef Marine Parks Zoning Map 7-Townsville; c. on the eastern margin of Gondwana (after Scotese and Barret 1990), note that the edges of continents do not represent shorelines; modern continents added in order to facilitate reading the map; d. A chronostratigraphic scheme of the Fanning River Group (combined after Talent and Mawson 1994; Zhen 1991, 1995, 1996) 
discuss whether Magnetic Island may represent a modern analogue for the Devonian Fanning River reef community.

\section{Materials and methods}

\section{Geological setting and sedimentological context- Fanning River}

The Burdekin River Basin (Queensland, Australia, Fig. 1a) is a Devonian-Carboniferous intracratonic extensional basin developed on the eastern tropical shelf of Gondwana (Fig. 1c), accumulating up to $4500 \mathrm{~m}$ of sediments (Lang et al. 1990). The basal part of this succession belongs to the Fanning River Group, composed of (in stratigraphic order) the clastic Big Bend Arkose Formation, carbonate-dominated Burdekin Formation (up to $500 \mathrm{~m}$ in thickness) and, at the top, clastic Cultivation Gully Formation (Cook 1994; Zhen 1996; Fig. 1d). The first two formations represent a transgressive and the latter a regressive phase (Zhen 1996).

The Fanning River study site $\left(19^{\circ} 48^{\prime} 26.1^{\prime \prime} \mathrm{S}\right.$ $\left.146^{\circ} 29^{\prime} 10.3^{\prime \prime} \mathrm{E}\right)$ is located south-west of Townsville ( $\sim 40 \mathrm{~km}$, Fig. 1a), between two small hills at the Fanning River Station. The transgressive sedimentary sequence exposed here starts with several $\mathrm{m}$-thick, fossiliferous, coarse-grained, commonly cross-bedded sandstones of the Big Bend Arkose Formation, covering crystalline basement and containing fragments of rugose corals. These arkoses were deposited close to the shoreline in a very shallowwater (less than $5 \mathrm{~m}$-deep) environment as a result of influx of siliciclastic material supplied by rivers draining the granitoidic hinterland (Cook 1994).

The arkoses pass gradually (with decreasing amount of siliciclastic material) into limestones of the Burdekin Formation, generally overlying the Big Bend Arkose Formation, but in places coeval with its upper part (Cook 1994). The Givetian age (probably middle to late varcus conodont Zone) of the Burdekin Formation is implied by its conodont (Cook 1994; Talent and Mawson 1994), brachiopod (Zhen 1991; Cook 1994) and rugose-coral (Zhen 1996) faunas.

The interval examined starts with a stromatoporoid biostrome, underlain by a $30-40 \mathrm{~cm}$ thick dark-grey limestone with lighter-coloured, reworked intraclasts. The biostrome is $\sim 20-40 \mathrm{~cm}$ thick, mostly composed of laminar but also low-domical frame-building stromatoporoids (no other fossils observed), nearly all in life positions that presumably formed the hard bottom. This unit is laterally exposed for over $300 \mathrm{~m}$ and it is traceable in the field due to its resistance to erosion (Fig. 2a), but no wellexposed bed surfaces are available for study.

The coral community bed immediately overlies the biostrome. It is a less weathering-resistant, micritic marly limestone that can be observed for over $300 \mathrm{~m}$. Hydrochloric acid etching of the rock samples provided minute amounts of silty residuum. It contains a coral community composed of massive, foliaceous, branching and encrusting tabulate corals, solitary and very rarely colonial, massive rugose corals (details below, see Figs. 2b, $3,4)$. The rugose corals were a subject of separate studies (Zhen 1991), and the rugose coral assemblage corresponds to the Dendrostella trigemme association sensu Zhen 1996. Tabulates have not been studied so far, therefore this study focuses on these corals. The large number of coral colonies are observed in situ in life positions (for massive colonies above $80 \%$, most of foliaceous and all encrusting taxa), with very few colonies observed lying on their sides (Fig. 2e). Corals are locally frame-building; this lithosome can be classified as autobiostrome or autoparabiostrome sensu Kershaw (1994).

Some of the fossils are preserved within micrite envelopes (Fig. 4g). Many fragments of branching corals are broken, with sharp edges of the broken surfaces (Fig. 2b, $3 b, d)$. Fine anatomical details of corals, including calyces (e.g. Fig. 3b), as well as long sections of fine coral branches are notably well preserved (e.g. Fig. 3a), attesting to local breakage and no significant transport of the material.

Co-occurring fauna is scarce; stromatoporoids in the coral bed are sparse; the rubble yielded rare brachiopods, probably stringocephalids and gypidulids (mostly visible as sections, Fig. 3b), both typical of Devonian shallow-water environments (e.g. Anderson and Makurath 1973; Baliński 1973). No other invertebrates typical for Devonian reef environments (trilobites, crinoids) were found except for a single gastropod; calcareous algae have also not been found.

\section{Survey on Magnetic Island}

A comparative survey was carried out at Magnetic Island ( $\sim 8 \mathrm{~km}$ offshore of Townsville, Queensland, Fig. 1a, b), a continental island located in shallow $(<10 \mathrm{~m})$ waters of Cleveland Bay, $5 \mathrm{~km}$ offshore from Townsville, Queensland. Magnetic Island supports fringing reefs, the best developed of which occur on its south-eastern side, particularly in Geoffrey and Nelly Bays (Bull 1982; Lewis et al. 2012). The environmental background of the Magnetic Island shore is controlled by the presence of granitoid headlands near the waterline, medium to coarse sand particles of the upper beach sediments (Morrissey 1980), and high sediment input in the shallow water (Lewis et al. 2012). Like Fanning River, Magnetic Island's reefs do not display any significant relief in sections parallel to the shore. Therefore, due to a very similar environmental setting, the coral communities present may represent an 

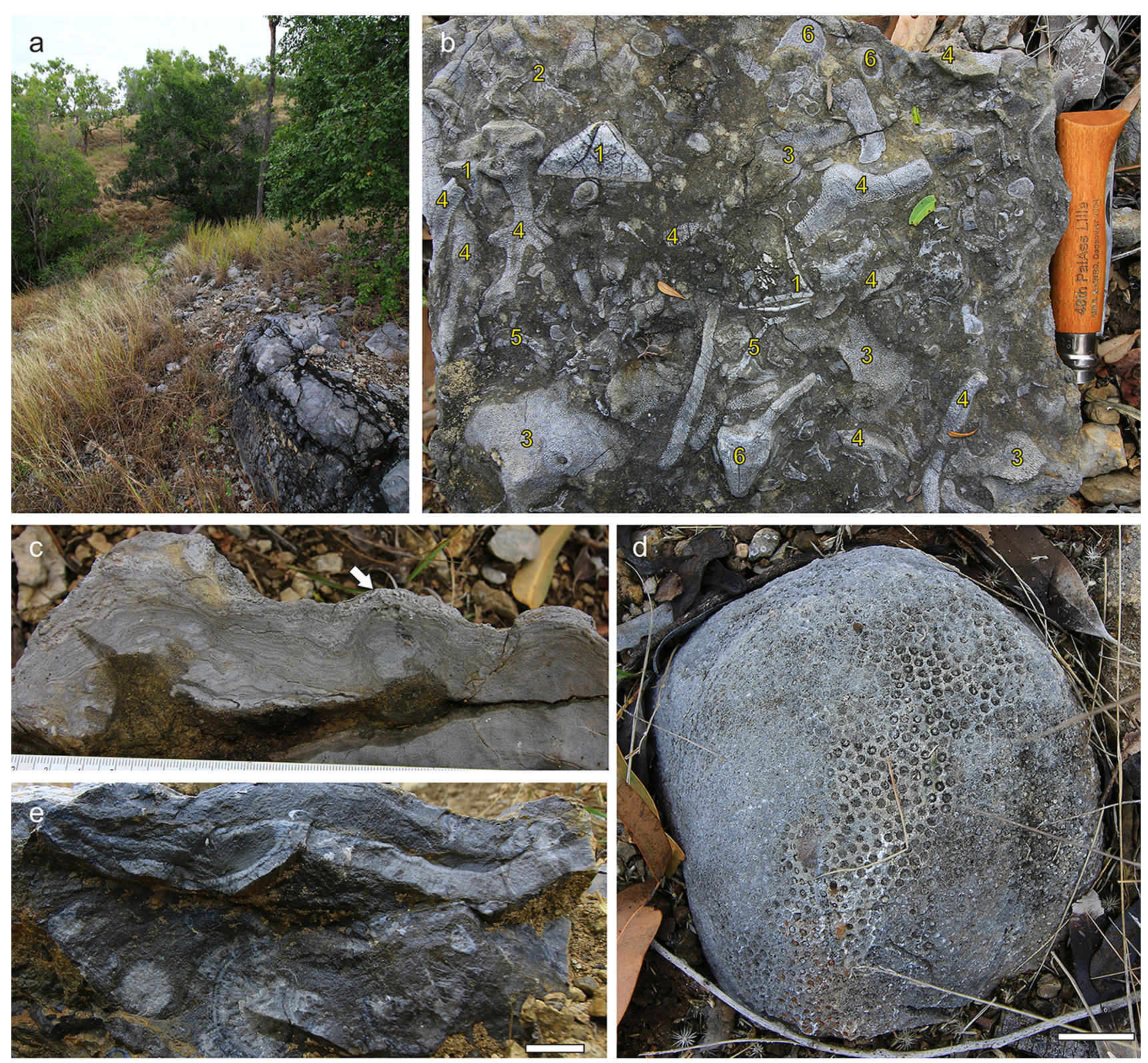

Fig. 2 Field photos of the study site near the Fanning River Station, Queensland, Givetian; a. General view of the stromatoporoid bed (light grey) overlying bed with intraclasts (darker gray); b. Tabulate and rugose corals: 1-Calceola sandalina (rugose), 2-Schluterichonus? sp. A, 3-irregular Alveolites fornicatus, 4-branching Alveolitella aff. densata, 5-branching Striatopora aff. schandiensis, 6solitary rugose corals; c. laminar stromatoporoid encrusted by

instructive modern analogue for the Devonian reefs of the Fanning River area.

The percentage cover and relative abundance of the following morphological groups of corals were quantified on Magnetic Island using Point Intercept Transects (e.g. Keith et al. 2018). Four replicate $50 \mathrm{~m}$ transects were run at $1 \mathrm{~m}$ and $6 \mathrm{~m}$ depths in the Geoffrey Bay and Nelly Bay on 1st August 2018 (additional dives were done in July 2019 during MKZ's stay in Townsville). All transects were auloporid, Mastopora aff. spicata (arrow), side view. Note the framework formed by overgrowths of tabulate and stromatoporoid; $d$. massive Heliolites porosus; e. foliose, vase-shaped Alveolites aff. saleei in situ (top), with solitary rugose coral and massive Heliolites porosus lying on its side below. Knife length $11 \mathrm{~cm}$, scale bars $20 \mathrm{~mm}$

pooled for the analysis. Coral colonies were identified to species and then grouped into morphologies as listed in Table S1. The morphological categories used were the same as for the fossil assemblage: encrusting; massive forming bulbous, domical and irregular colonies; foliaceous taxa, including funnel-shaped; branching open and solitary. In addition, a sixth morphological group was introduced to take account of morphologies that do not occur in the fossil record, i.e. tabular and corymbose 
morphologies. Colony shape terminology follows Madin et al. (2016).

\section{Fossil study-methods, materials and repository}

During the fieldwork in June-September 2019, we collected over 80 coral samples, some specimens containing fragments of multiple taxa. It is impossible to determine coral cover in the fossil record, particularly when only cross- and oblique-sections of the bed are available. Therefore, our field estimations of various morphological types of colonies are based on the bed and rubble observations. We have prepared 23 polished slabs, 13 large
Fig. 4 Polished slabs and thin sections of specimens. a. curled fragments of Alveolites cf. fornicatus; $\mathbf{b}$. irregular Alveolites fornicatus; c. massive (ragged) colony of Alveolites fornicatus from the rubble, evidencing high sedimentation rate. Note a stromatoporoid serving as a substratum for coral (black arrow) and multiple rejuvenations above the zones of growth cessation (white arrows) due to high sediment input; d. platy Alveolites aff. saleei, and Calceola sandalina (triangular). e. platy Roseoporella sp. A (1) and branching Coenites aff. uralensis (2); f. skeletons of various organisms forming the coral community sediment. Stromatoporoid at the bottom is overgrown by Mastopora aff. spicata (arrow). Note broken fragments of branches and colonies, with sharp edges; g. rugose coral with micritic envelope; $\mathbf{h}$. massive (ragged) colony of Alveolites fornicatus evidencing high sedimentation rate. Note intergrowth with a stromatoporoid, and rejuvenation of coral growth. Fanning River Station, Queensland, Givetian. Scale bars $10 \mathrm{~mm}, 2$ $\mathrm{mm}(\mathrm{h})$.
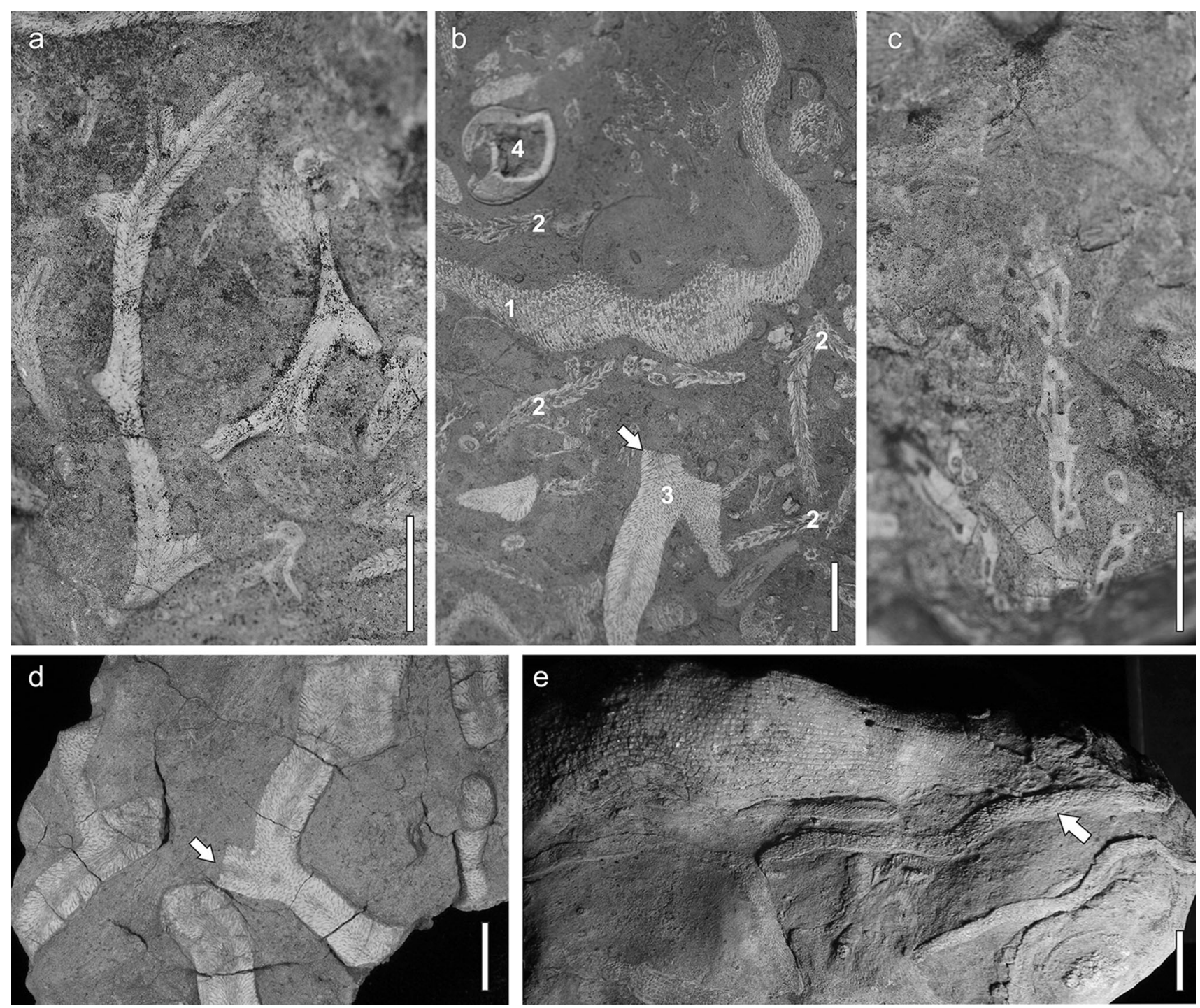

Fig. 3 Weathered surfaces of specimens. a. Coenites aff. uralensis ; b. Various corals: 1-Alveolites aff. saleei, 2-Striatopora aff. schandiensis 3-Alveolitella aff. densata, 4-brachiopod shell. Arrow shows broken edge of branch; c. branching auloporid Schluterichonus? sp.
A; d. Coenites sp. A, arrow shows broken edge of branch; e. rugose coral on platy Alveolites aff. saleei. Arrow shows point of attachment. Fanning River Station, Queensland, Givetian. Scale bars $10 \mathrm{~mm}$ 


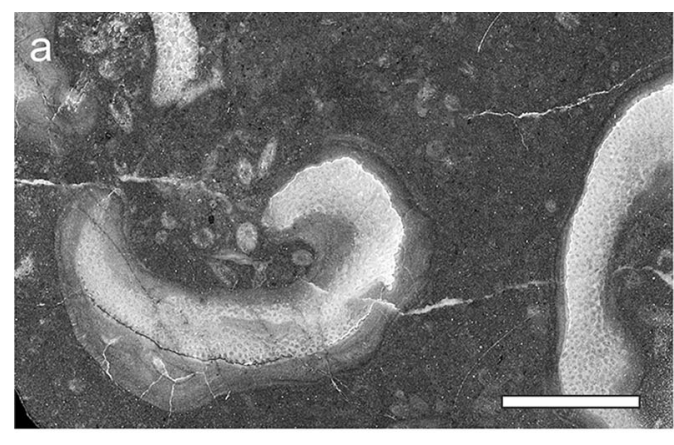

C
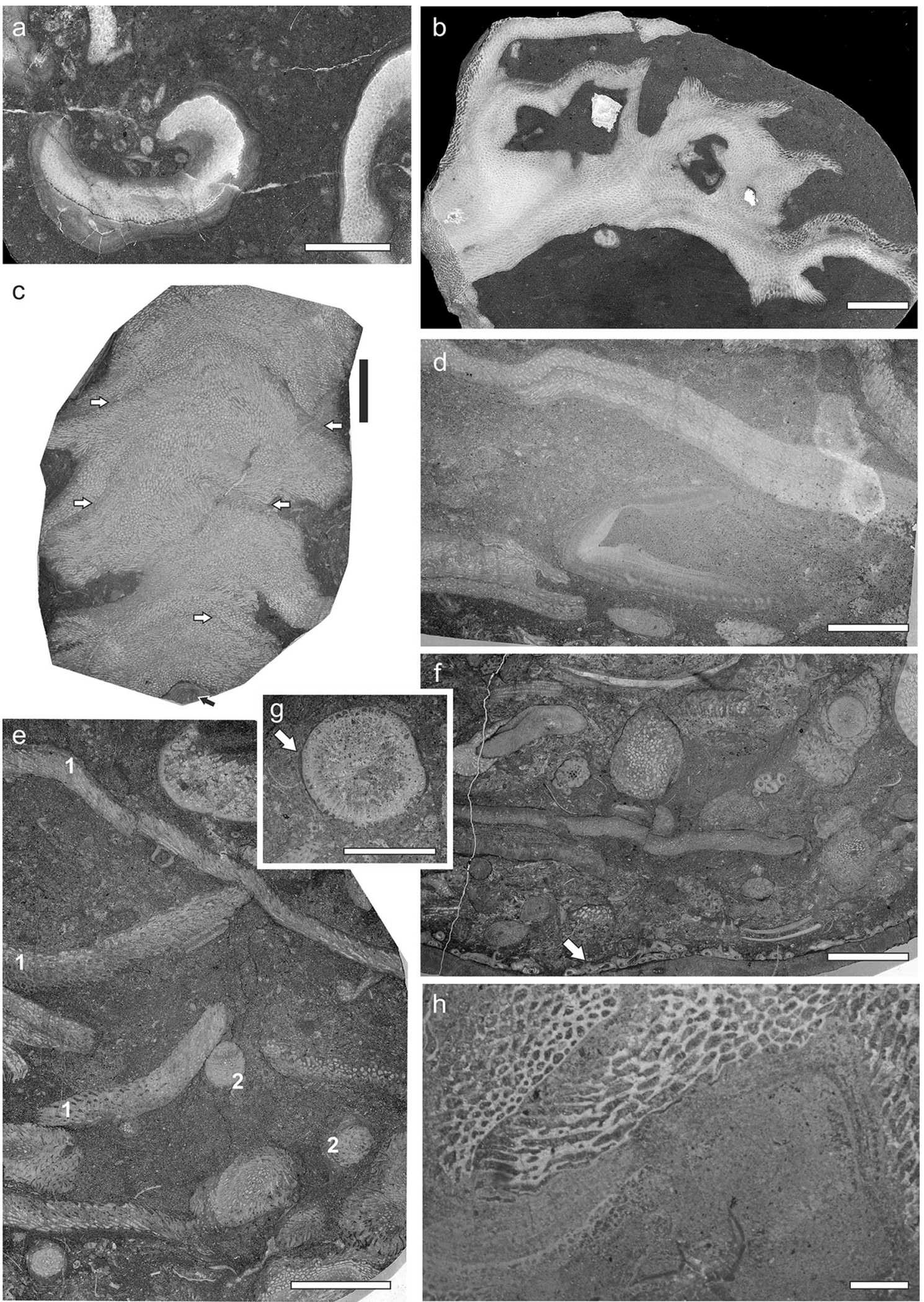
$(4 \times 6 \mathrm{~cm})$ and 15 small $(2 \times 3 \mathrm{~cm})$ thin sections, and 10 polished slabs etched in hydrochloric acid.

The specimens illustrated here are deposited in the Museum of Tropical Queensland, Townsville, Australia and at the Museum of The Faculty of Geology, University of Warsaw, Warsaw, Poland. Field photos were taken with a Canon EOS 70D camera and a 10-18 mm zoom lens (edges of field photos may have distortion), and specimens were photographed with either a $100 \mathrm{~mm}$ macro lens or a 70-300 mm zoom lens. Thin sections were either photographed using the above-mentioned camera and a Zeiss Discovery V20 stereoscopic microscope, or scanned with an Epson Perfection V800 scanner. Contrast and sharpness adjustments in each case have been applied to the whole photograph.

\section{Results}

\section{The Givetian coral community at Fanning River}

The coral community is composed of several morphological groups:

\section{Encrusting taxa}

2. Foliaceous taxa, including funnel shaped forms

3. Massive taxa forming bulbous, domical and irregular colonies

4. Branching taxa

5. Solitary taxa

The coral community generally developed directly on the stromatoporoid substratum, often by pioneering encrusting tabulates including the auloporids Aulopora serpens, $A$. aff. serpens and Mastopora aff. spicata (Figs. 2c, 4f). Colony integration in these taxa is very low (no connections of polyps, except when budding; separated walls) and corallite diameters are $<1.5 \mathrm{~mm}$. Colonies were up to $\sim 30 \mathrm{~cm}$ in diameter (rough estimation from fragments). Auloporids sometimes overgrew colonies of other corals including solitary rugose corals, presumably post mortem. A significant element of encrusting tabulate group are coenitids, e.g. Roseoporella sp. A that formed very thin (up to $1 \mathrm{~cm}$ ) blades and crusts, often directly on micrite (Fig. 4e). Representatives of Roseoporella are characterized by moderately to highly integrated coloniescerioid, with shared perforate walls, and submilimetric corallites. The whole bed containing the coral community varies laterally, with some parts dominated by foliaceous and encrusting forms, others branching tabulates, and in some either massive forms or solitary rugose corals. The abundance of encrusting forms is estimated at 5-15\%.

Foliaceous tabulates are common in this community and are represented by coenitids Roseoporella sp. A (Fig. 4e, f), and alveolitids Alveolites aff. saleei (Fig. 3b, 4d) with corallites on upper surfaces of the frond only (Figs. 2e, 3b, e, 4d, e, f), and Platyaxum sp. (coenitid) with bifaced fronds. The latter corals form fronds of couple of $\mathrm{cm}$ in length (rarely exceeding $10 \mathrm{~cm}$ ), and may have possibly formed funnel-shaped coralla. Integration of these colonies was moderate, with shared, rarely perforated walls (cerioid structure) and corallite diameters $<1.0 \mathrm{~mm}$. A. aff. salee grew as laterally extending fronds reaching $>20 \mathrm{~cm}$ in length that formed broad, funnel-shaped coralla, in some cases nearly flat (Fig. 3e). Both Roseoporella and Alveolites representatives formed sometimes bowl-shaped colonies, with edges curled inwards (Fig. 4a). It is difficult to estimate the total abundance of this type of colonies, as they often occur as broken fragments, but foliaceous taxa together probably constituted $25-35 \%$ of the community.

Massive taxa constitute $30-50 \%$ of specimens observed in the field. They are dominated by the tabulate Heliolites porosus (Fig. 2d), a species that is the most visible element of the community ( $\sim 80 \%$ of massive colonies). $H$. porosus were up to $30-40 \mathrm{~cm}$ in diameter, typically somewhat smaller. Colony integration was relatively high; they possess intercorallite tissue, but imperforated walls, and have corallite diameters up to $2.0 \mathrm{~mm}$. Another massive tabulate, Alveolites fornicatus, forms small, irregular colonies generally $<15 \mathrm{~cm}$ in the largest dimension. These colonies often form thin, irregular outgrowths (Fig. 4a, b) and display ragged growth with growth interruption surfaces and rejuvenation (Fig. 4c, h). The alveolitids have moderate colony integration, with cerioid structure, and shared, perforate walls; corallites are usually submilimetric. We also found single specimens of two more species: a small ( $<10 \mathrm{~cm}$ diameter), massive colony of Syringopora crispa with low colony integration (phaceloid, with solitary walls and rare interconnections between polyps of about $2 \mathrm{~mm}$ in diameter), and a partial colony of Xystriphyllum? sp. (Rugosa; previously unknown from these beds), which may have exceeded $30 \mathrm{~cm}$ in diameter. It has a phaceloid cerioid structure (shared, imperforate walls) and large corallite diameters ( $20 \mathrm{~mm})$.

Branching corals belong to several taxonomic groups (Figs. 2b, 3). All formed very thin branches, generally $<5 \mathrm{~mm}$ in diameter, although some Alveolitella aff. densata and Dendrostella trigemme branches reached $15 \mathrm{~mm}$. As they are broken branches it is impossible to estimate the size of the whole colonies. Branching tabulates represent multiple taxa including alveolitids (Alveolitella aff. densata, thicker branches, Figs. 2b, 3b), pachyporids (Striatopora aff. schandiensis; thinner branches, Fig. 3b), and coenitids (Coenites aff. uralensis, thin branches, Fig. 3a, Coenites sp. A, thicker branches, Fig. 3d), as well as auloporids, Schluterichonus? sp. A that 
Table 1 Estimated percentages of coral morphologies in the Fanning River coral community

\begin{tabular}{ll}
\hline Morphology & Estimated percentage (\%) \\
\hline Encrusting & $5-15$ \\
Foliaceous (frondescent) & $25-35$ \\
Massive & $30-50$ \\
Branching taxa & $15-30$ \\
Solitary taxa & $<5$ \\
\hline
\end{tabular}

formed short, fine branches (Fig. 3c). A separate group is formed by phaceloid, branching rugose Dendrostella trigemme (see Zhen 1991), very rare in this particular bed. Whilst branching corals are clearly very abundant, their occurrence as fragments makes it difficult to quantify their contribution to the community, but may range from 15 to $30 \%$.

Solitary taxa are represented uniquely by rugose corals. The rugosans show low morphological diversity, with prevalence of conical, triangular-shaped Calceola sandalina (Fig. 2b) and cylindrical forms. They are usually $10-30 \mathrm{~mm}$ in diameter, but can exceed $40 \mathrm{~mm}$ in diameter. When observed in situ they occur in clusters of individuals, and may form weakly integrated phaceloid pseudocolonies. The most common species are Pseudomicroplasma australe, Acanthophyllum spp., Stringophyllum quasinormale, Temnophyllum sp. and Charactophyllum trochoides (Zhen 1996). Although solitary taxa are abundant and visible in the field, they did not contribute substantially to total coral cover due to their small sizes (estimated at $<5 \%$ ). Estimates of the abundance of all morphological forms of colonies are summarized in Table 1.

\section{The modern assemblage}

The encrusting taxa are represented by members of the genera Astreopora, Echinopora, Galaxea, Hydnophora, Merulina, Montipora, Oxypora, Pavona, Podabacia and Psammocora (16 spp). The foliaceous taxa are less diverse, and represented by species of the genera Montipora, Pachyseris, and Turbinaria (five spp.). Massive corals are most diversified (19 spp.) and represent species belonging to Astrea, Cyphastrea, Dipsastrea, Euphyllia, Favites, Goniopora, Goniastrea, Lobophyllia, Moseleya, Platygyra, Plesiastrea and Porites. Taxa belonging to genera Acropora, Pocillopora, Seriatopora and Stylophora (7 spp.) form the "branching open" group, whilst the "branching other" species are solely representatives of the genus Acropora ( 8 spp.). Solitary corals are represented by four species (Ctenactis, Heliofungia, Heteractis, Pleuractis). The most typical examples of the Geoffrey and Nelly Bay coral communities are shown in Fig. 5. The detailed species list with abundancies of colonies are given in the S1 table.

\section{Coral assemblage structure}

The total coral cover at Magnetic Island was approximately $22 \%$. Foliaceous colonies were the most abundant morphology, followed by massive and encrusting form, then branching with solitary colonies the least abundant (Fig. 6). In terms of relative abundance of each morphology as a proportion of the total coral assemblage, foliaceous species accounted for $35 \%$ of the colonies, encrusting and massive colonies accounted for approximately $25 \%$ each, with solitary colonies comprising less than $2 \%$ of the total coral cover.

\section{Discussion}

\section{The environmental interpretation}

Both the taxonomic composition and range of morphologies in the Devonian coral assemblage can be understood primarily in the context of the combination of the shallow water depth and high sedimentation rate that characterized the Fanning River reef (Lang et al. 1990; Cook 1994). Sedimentological data, notably the gradual passage from coarse-grained siliciclastics through fine-grained siliciclastics to carbonates, indicates that the beds were deposited in a transgressive sequence and in a relatively shallowwater environment. Below and above the investigated beds, bioclast- and intraclast rich horizons occur. Cook (1994) interpreted these horizons as recording storm events, an interpretation which further constrains the maximum depth of the studied succession to $20 \mathrm{~m}$, i.e. the maximum depth at which the largest hurricanes can break or damage coral colonies (Scoffin 1993). Given that this part of sequence is transgressive and that the intraclast-containing horizons occur above the analysed part of the section, the absolute depth of the coral community must have been $<20 \mathrm{~m}$. Cook (1994) interpreted the coral- and stromatoporoid-rich unit as deposited at a shallow depth $(<10 \mathrm{~m}$ and as shallow as $2-3 \mathrm{~m}$ ), clearly above the storm wave-base, in a partially protected (possibly lagoonal) environment. This is in agreement with the presence of stringocephalid and gypidulid brachiopods, typical shallow-water dwellers (Anderson and Makurath 1973; Baliński 1973).

The presence of micrite envelopes (Fig. 4g), observed around some of the studied fossils, is also typical of very shallow-water environments (Flügel 2004). Swinchatt (1969) has shown that such envelopes occur commonly in environments $<18-20 \mathrm{~m}$. The abundant broken coral fragments, particularly branching corals, provide further evidence of high-energy events typical of shallow environments. Fine details of coral calyces are well preserved, and a number of fragments are broken with sharp edges of 

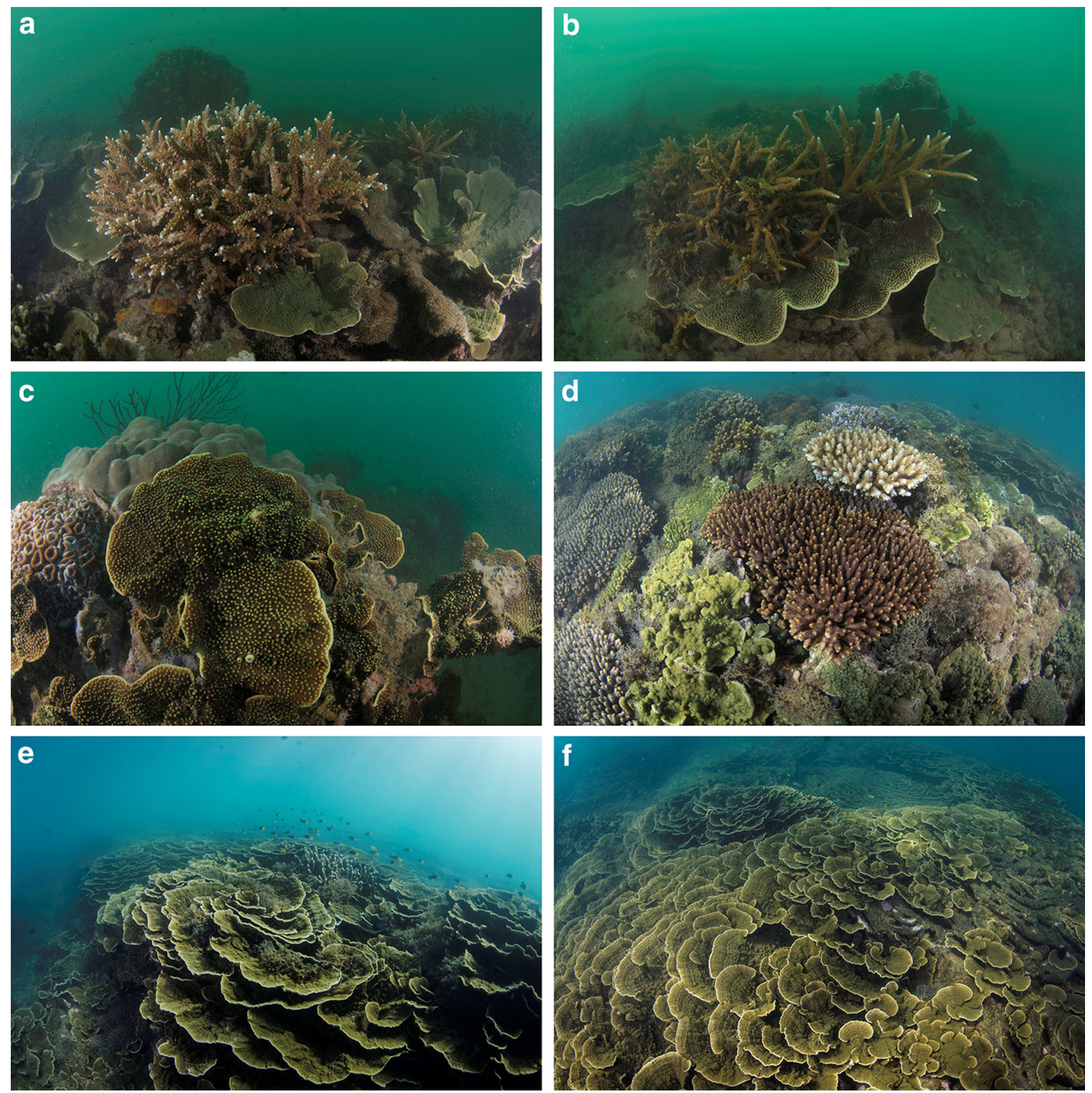

Fig. 5 Examples of modern scleractinian coral assemblages on a turbid inshore fringing reef at Magnetic Island, Queensland, Australia. a, b. Staghorn Acropora and platy Turbinaria; c. platy

Turbinaria with massive Porites and Dipsastrea in the background; d. corymbose Acropora with encrusting Montipora; e, f. monospecific stands of foliose Montipora. Photo by Tom Bridge

broken surfaces (Figs. 3b, d, 4f). Fine branches are often preserved as longer fragments (Fig. 3a), implying very limited transport of the fragmented material. This preservation state suggests a relatively rapid burial of the bioclasts and indicates a high sedimentation rate and highturbidity environment.

The high contribution of Heliolites sp. (about $80 \%$ of massive colonies) is significant to the environmental

interpretation. The massive heliolitids were characteristic of environments located above the storm wave-base and typified by generally moderate hydrodynamic energy with episodes of high energy conditions and the capacity to thrive under high sediment influx (Król et al. 2018). Accordingly, the dominance of massive heliolitids is most typical of middle Palaeozoic coral communities subjected to increased water turbidity (Baarli et al. 1992; Jakubowicz et al. 2019). 


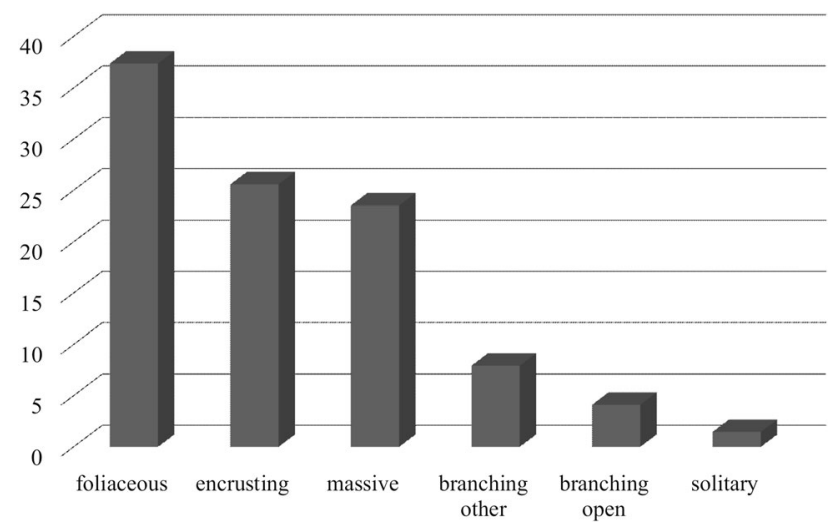

Fig. 6 Composition of the morphological types of coral colonies from the Geoffrey and Nelly Bays, Magnetic Island

Taken together, the sedimentological data consistently point the Fanning River coral community occurring in a very shallow-water, inner-shelf setting with high sedimentation rates and low water clarity (Table 2). This is supported by a sedimentological study by Lang et al. (1990), who demonstrated that these biostromal beds represent a structure that was possibly resistant to wave action and forming a fringing reef.

Such paleoenvironmental conditions are remarkably similar to the fringing coral reefs at Magnetic Island, located in an environmental setting characterized by a shallow water depth (less than $10 \mathrm{~m}$ ), with tops of the reefs exposed at the lowest tides, relatively high influx of terrigenous sediment supplied by nearby rivers (Ross River, Alligator Creek, Crocodile Creek), and associated low optical quality of water (Fig. 5).

\section{Coral morphologies}

Coral colonies show remarkable adaptations to high sedimentation rates and turbidity. The foliose colonies of alveolitids and coenitids, sometimes forming funnels are typical of high-sediment environments. Under high water movement, the funnel morphology creates vortices removing sediment from the tissues, whereas in periods of lower water movement the sediment concentrates in lower parts of the colony causing local necrosis whilst all other parts remain alive and are able to capture food and harvest light (Riegl et al. 1996; Anthony et al. 2005). Platy and foliose morphologies, on the other hand, suggest low light availability and, like their modern analogues, are likely an adaptation to low levels of PAR (Kahng et al. 2012), resulting from high turbidity in the water column.

A notable feature of the Fanning River community is the presence of the irregular alveolitids with numerous outgrowths of the colony (Fig. 4b), occurring in the form of blades, plates and horns. Such colony shapes, together with platy-curled forms (Fig. 4a), are interpreted as a mean of sediment removal in a high sedimentation regime (Leinfelder 2001). Blades and outgrowths at the edge of a colony reflect greater freedom of division of corallites, and might help in avoiding sediment accumulation on soft tissue (Barnes 1973). In some cases, the sediment cover presumably resulted in partial mortality of soft tissues, resulting in rejuvenations of coral colonies (Fig. 4c, h).

\section{Epibionts}

Epibionts are relatively rare in the Fanning River coral community, as compared to comparable strata from Europe (e.g. Zatoń et al. 2018). These are mostly auloporids, corals considered to be either opportunistic encrusters in biostromal settings (Zatoń et al. 2015) or potentially selective encrusters in the case of brachiopod substrata (Zapalski 2005; Mistiaen et al. 2012). In the Fanning River community, they encrusted stromatoporoids (Figs. 2c, 4f), other tabulates or solitary rugose corals, so seem rather opportunistic. Rugose coral larvae may have settled on
Table 2 Summary of sedimentological and palaeontological evidences of environmental features of the Fanning River reef

\begin{tabular}{ll}
\hline Feature & Evidence \\
\hline Shallow environment & $\begin{array}{l}\text { Location at the bottom of a transgressive sequence } \\
\text { Intraclasts below and above the biostrome } \\
\text { Presence of micritic envelopes }\end{array}$ \\
& $\begin{array}{l}\text { Presence of gypidulids and stringocephalids } \\
\text { Fine external details of coral skeletons preserved } \\
\text { Lack of transport (lack of strong currents) }\end{array}$ \\
Periodical high-energy events (storms) & $\begin{array}{l}\text { Broken fine branching corals } \\
\text { Intraclasts below and above the biostrome }\end{array}$ \\
High sedimentation rates & $\begin{array}{l}\text { Lack of epibionts on lower surfaces of coral colonies } \\
\text { Rugged and funnel-shaped coral morphologies }\end{array}$ \\
Large contribution from Heliolites \\
Low ambient light
\end{tabular}


platy and foliose tabulates, as evidenced by a single specimen of a rugose coral attached to the platy Alveolites sp. (Fig. 3e). The scarcity of epibionts may be attributable to the high sedimentation rate, and associated rapid burial of the undersides of the foliose colonies, limiting their availability as hard substrate for settlement (Zapalski et al. 2017b).

\section{The coral communities}

The above-described fossil coral community developed on the stromatoporoid biostrome. Devonian shallow-water reef communities were typically dominated by stromatoporoids rather than corals (e.g. Scrutton 1998; Kershaw et al. 2018), with stromatoporoids thought to prefer low sedimentation rates and clear water (Königshof and Kershaw 2006). Corals, especially tabulates, preferred calmer, deeper environments, and often occur as the deepest (within the photic zone) biozone in deepening sequences, bathymetrically below stromatoporoids in zonation (Lecompte 1958; Embry and Klovan 1972). Given that the sequence studied is transgressive, a possible scenario is that the stromatoporoid biostrome developed in shallower water under conditions of low sedimentation rates, but an increase in depth and decrease in water clarity resulted in stromatoporoids being outcompeted by tabulate and rugose corals that were better equipped to deal with high sedimentation.

In contrast, previously reported middle Palaeozoic coral communities with a large contribution from foliaceous tabulates likely represent mesophotic settings, deeper than the Fanning River community (Zapalski et al. 2017b; Zapalski and Berkowski 2019). These mesophotic communities differ from the Fanning River community by the near absence of massive colonies, higher diversity of co-occurring fauna (abundant brachiopods and crinoids), and presence of chaetetid sponges. At the genus level, the coral taxa are the same in both true Devonian MCEs, and in the Fanning River "brown-water mesophotic" community (reefs in shallow water with low light due to high turbidity, Renema 2019).

The taxonomic diversity of the Fanning River coral ecosystem was relatively low, comprising 14 identified species of tabulates. Zhen (1996) recorded an additional 17 species of rugose corals from these beds, therefore the total confirmed coral species richness is 32 species (including Xystriphyllum? sp.). This suggests species richness of Fanning River was lower than the scleractinian communities at Magnetic Island. This is not surprising given that Devonian reefs supported fewer species than their recent analogues: the tabulate coral biodiversity for the whole Middle Devonian in the Ardennes is $\sim 70$ species, but it must be taken into account that stromatoporoids formed a large part of the constructional guild of that time (Hubert et al. 2007). The recently described Givetian Jiwozhai reef from China (Huang et al. 2020) shows similar biodiversity of tabulate corals (13 species), with overall higher diversity of all other taxa (representatives of 8 phyla). The taphonomic bias might also decrease preserved biodiversity. All genera present in the Fanning River community had cosmopolitan distribution during the Givetian and Frasnian (e.g. Birenheide 1985; Zapalski 2012). Coeval tabulate assemblages known from Europe are similar in overall taxonomic composition (e.g. Birenheide 1985; May 1993; Zapalski et al. 2007; Zapalski 2012), yet they differ in proportions of various morphological types of colonies. Foliaceous taxa are generally rare whilst the branching forms (pachyporids and coenitids) are similarly abundant, suggesting that the Fanning River community is unusual for the Devonian.

The coral communities of the Geoffrey and Nelly Bays are similar in terms of the abundance of different morphological groups, with foliaceous colonies being most abundant, followed by massive, branching, and solitary taxa. This community is typical of protected, turbid inshore reefs on the GBR and throughout the Indo-Pacific, which are often dominated by foliaceous (e.g. Echinopora, Turbinaria, Leptoseris, Montipora), massive-submassive (Porites, Goniopora) or very fine-branching (Seriatopora) taxa (e.g. DeVantier et al. 2006). Turbid and low-light reefs present particular challenges to corals, involving a trade-off between maximizing light capture whilst also allowing for removal of accumulated sediments, leading to characteristic assemblages in both 'brown-water' and 'blue-water' mesophotic habitats. The similarities in both the morphological composition and relative abundance between the rugose and tabulate coral communities of Fanning River and the scleractinian communities at Magnetic Island suggest both groups converged on similar strategies for dealing with sedimentation. Given the distant relationship between Palaeozoic corals and modern Scleractinia it is unsurprising that some differences exist between the groups: for example, there appears to be no analogue for corymbose or hispidose morphologies in the Palaeozoic, although these complex growth forms are rare even in the Scleractinia, being restricted to the genus Acropora. Nonetheless, the similarities in the two assemblages separated by 385 million years suggest that high-sedimentation rate environments strongly influence the morphological composition of coral communities.

\section{Ecological similarities between fossil and recent corals}

Given the strong association between morphology, environment and life history strategies (Jackson and Hughes 1985; Strathmann 1996), it seems likely that corals with similar gross morphology (external shape) and structure 

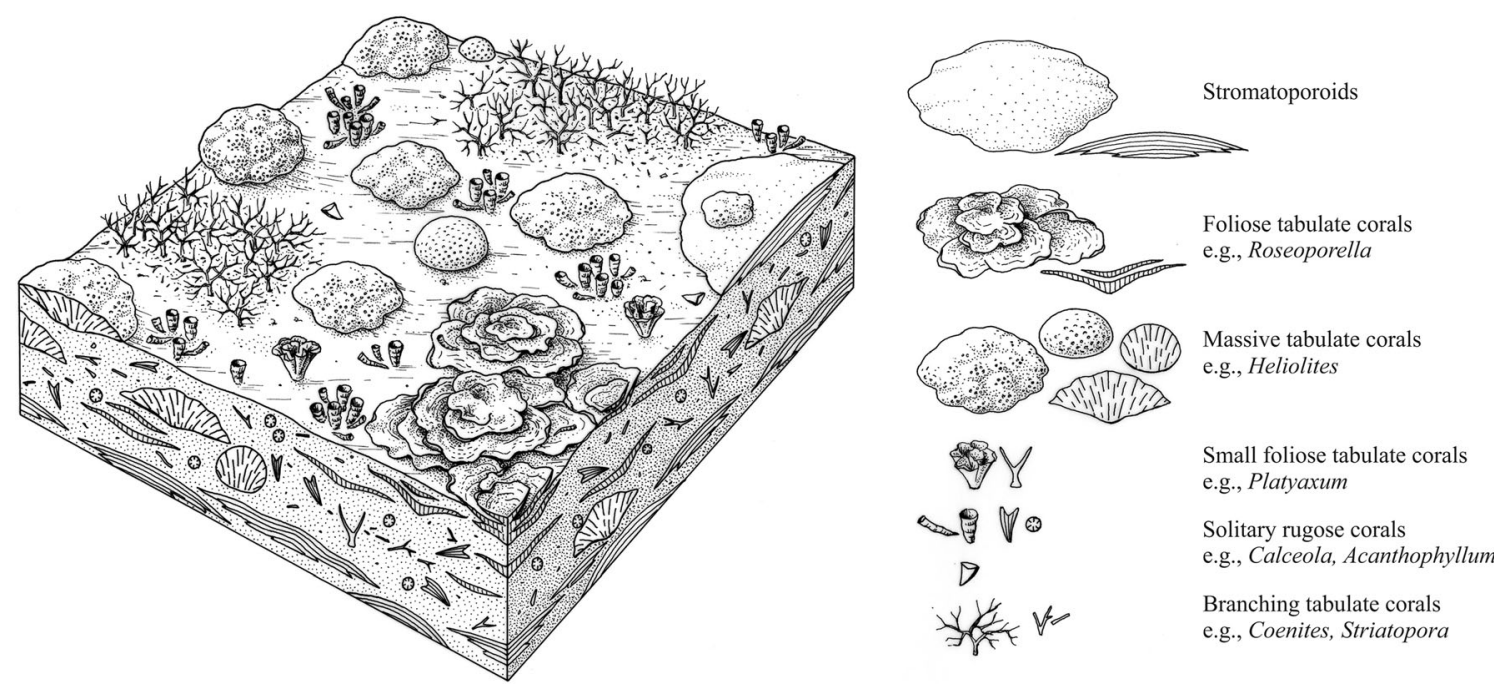

Fig. 7 Reconstruction of the Fanning River reef, Fanning River Station, Queensland, Givetian. Drawing by B. Waksmundzki

(e.g. polyp size, which may be related to feeding habits, Porter (1976)) occupy similar ecological niches within the Phanerozoic coral reef communities. If true, then we can reason that foliose coenitids-Platyaxum and Roseoporella played an ecological role similar to Turbinaria and Montipora on contemporary reefs. The small polyp diameter in Montipora $(<1 \mathrm{~mm})$ suggests it may be the closest analogue for the latter genus. The massive, plocoid colonies of heliolitids-Heliolites, with small corallites not exceeding $2 \mathrm{~mm}$, were ecologically similar to Porites, whereas the branching coenitids-Coenites and pachyporids-Striatopora were potential ecological analogues of Acropora. The branching alveolitids, Alveolitella, with small corallites $(<1 \mathrm{~mm})$ and somewhat irregular branches may have been ecologically similar to Seriatopora. Encrusting tabulates, such as Roseoporella and Alveolites were ecologically similar to Montipora spongodes. The large solitary cystiphyllids and Calceola (Rugosa) might have played a role similar to fungiids (Pleuractis, Ctenactis, Heliofungia), despite fungiids generally displaying larger polyp sizes.

Total coral cover on Magnetic Island is currently $\sim 22 \%$, lower than nearby reefs with clearer water (30-40\%, unless recently disturbed, e.g. Madin et al. 2018), suggesting this environment is less than optimal for coral growth. The coral cover of the Fanning River community cannot be estimated from the available data, but the differences between Fanning River and other Devonian coral communities do indicate that the turbidity clearly influenced Devonian communities, as it does in modern Scleractinia. Magnetic Island assemblages are also dominated by morphologies that are typically rare on low turbidity reefs. For example, massive and encrusting species make up less than $30 \%$ of total cover on a typical reef crest assemblage, compared to branching species that make up most of the remaining 70\% cover (Baird et al. 2018).
Indeed, in terms of the relative abundance of colony morphologies, the Magnetic Island coral assemblages are closer to the Fanning River reef community (Fig. 7) than to nearby scleractinian reefs in clear water.

We postulate that the unusual, inner shelf Givetian coral community from Fanning River, dominated by massive and platy-foliose growth forms of the tabulate corals, shows numerous adaptations to shallow, turbid environments characterized by depleted light levels. This community shows notable similarities to the extant Magnetic Island coral communities in terms of their functional morphology. The Fanning River reef, together with the recent discoveries of Palaeozoic MCEs suggest that reefs of that time may be more analogous to modern reefs than traditionally thought. We can conclude that the geological record of these inshore, high turbidity-adapted coral communities can be traced back about 385 Ma.

Acknowledgements We are very grateful to Ian Somerville (Dublin) and two anonymous referees for their comments that significantly improved this paper. MKZ benefited from the Polish National Agency for Academic Exchange (NAWA), Bekker Scholarship that enabled the start of cooperation between the authors, and the fieldwork. The research has been funded by National Science Centre of Poland, project 2018/29/B/ST10/00954 to MKZ. AHB is supported by the Australian Research Council Centre of Excellence for Coral Reef Studies. MKZ wishes to express his thanks to Adam T. Halamski (Warsaw) for critical reading one of the earlier versions of the manuscript. Tomasz Wrzołek (Sosnowiec) is thanked for help with determination of a rugose corals. Authors are deeply grateful to Bogusław Waksmundzki (Warsaw) for drawing the reconstruction of the coral community. Grzegorz Widlicki (Warsaw) is kindly thanked for the preparation of thin sections and polished slabs.

\section{Compliance with ethical standards}

Conflict of interest On behalf of all authors, the corresponding author states that there is no conflict of interest. 
Open Access This article is licensed under a Creative Commons Attribution 4.0 International License, which permits use, sharing, adaptation, distribution and reproduction in any medium or format, as long as you give appropriate credit to the original author(s) and the source, provide a link to the Creative Commons licence, and indicate if changes were made. The images or other third party material in this article are included in the article's Creative Commons licence, unless indicated otherwise in a credit line to the material. If material is not included in the article's Creative Commons licence and your intended use is not permitted by statutory regulation or exceeds the permitted use, you will need to obtain permission directly from the copyright holder. To view a copy of this licence, visit http://creativecommons. org/licenses/by/4.0/.

\section{References}

Anderson EJ, Makurath JH (1973) Palaeoecology of Appalachian gypidulid brachiopods. Palaeontology 16:381-389

Anthony KRN, Hoegh-Guldberg O (2003) Variation in coral photosynthesis, respiration and growth characteristics in contrasting light microhabitats: an analogue to plants in forest gaps and understoreys?. Funct Ecol 17:246-259

Anthony KRN, Hoogenboom MO, Connolly SR (2005) Adaptive variation in coral geometry and the optimization of internal colony light climates. Funct Ecol 19:17-26

Baarli BG, Johnson ME, Keilen HB (1992) Size and shape distribution of level-bottom tabulate corals and stromatoporoids (Silurian). Lethaia 25:269-282

Baird AH, Alvarez-Noriega M, Cumbo VR, Connolly SR, Dornelas M, Madin JS (2018) Effects of tropical storms on the demography of reef corals. Mar Ecol Prog Ser 606:29-38

Baliński A (1973) Morphology and paleoecology of Givetian brachiopods from Jurkowice-Budy (Holy Cross Mountains, Poland). Acta Palaeontol Pol 18:269-297

Barnes DJ (1973) Growth in colonial scleractinians. Bull Mar Sci 23:280-298

Birenheide R (1985) Chaetetida und tabulate Korallen des Devon. Leitfossilien 3:1-249

Bull GD (1982) Scleractinian Coral Communities of Two Inshore High Island Fringing Reefs at Magnetic Island, North Queensland. Mar Ecol Prog Ser 7:267-277

Burchette TP (1981) European Devonian reefs: a review of current concepts and models. SEPM Special Publication 30:85-142

Coates AG, Jackson JB (1987) Clonal growth, algal symbiosis, and reef formation by corals. Paleobiology 13:363-378

Cook AG (1994) Sedimentology and depositional environments of the Middle Devonian lower Fanning River Group (Big Bend Arkose and Burdekin Formation), Burdekin Subprovince, North Queensland, Australia. Mem Queensl Mus 38:53-91

Copper P (2002a) Silurian and Devonian reefs: 80 million years of global greenhouse between two ice ages. SEPM Special Publication 72:181-238

Copper P (2002b) Reef development at the Frasnian/Famennian mass extinction boundary. Palaeogeogr Palaeoclimatol Palaeoecol $181: 27-65$

Copper P (2011) 100 million years of reef prosperity and collapse: Ordovician to Devonian interval. The Paleontological Society Papers 17:15-32

Copper P, Scotese CR (2003) Megareefs in Middle Devonian supergreenhouse climates. Geological Society of America Special Paper 370:209-230

DeVantier LM, De'ath G, Turak E, Done TJ, Fabricius KE (2006) Species richness and community structure of reef-building corals on the nearshore Great Barrier Reef. Coral Reefs 25:329-340
Embry AF, Klovan JE (1972) Absolute water depth limits of Late Devonian paleoecological zones. Geol Rundsch 61:672-686

Fagerstrom JA (1994) The history of Devonian-Carboniferous reef communities: extinctions, effects, recovery. Facies 30:177-191

Flügel E (2004) Microfacies of carbonate rocks: analysis, interpretation and application. Springer Verlag

Gischler E (1995) Current and wind induced facies patterns in a Devonian atoll: Iberg Reef, Harz Mts., Germany. Palaios 10:180-189

Graus RR, Macintyre IG (1976) Light control of growth form in colonial reef corals: computer simulation. Science, 193(4256):895-897

Hallock P (2005) Global change and modern coral reefs: new opportunities to understand shallow-water carbonate depositional processes. Sediment Geol 175:19-33

Hill D (1981) Tabulata. In Moore RC, Teichert C (eds) Treatise on invertebrate paleontology. Part F, Coelenterata. Supplement 1(2). The Geological Society of America, Boulder, and The University of Kansas, Lawrence, pp F430-F762

Huang J, Liang K, Wang Y, Liao W, Guo W, Kershaw S, Jeon J, Qiao L, Song J, Ma J, Li Y, Tu B, Tian Y, Wang Y, Wang Y, Ma J, Luo M, Li Y (2020) The Jiwozhai patch reef: A palaeobiodiversity hotspot in middle Givetian (Devonian) of South China. Palaeogeogr Palaeoclimatol Palaeoecol 556:109895

Hubert BLM, Zapalski MK, Nicollin J-P, Mistiaen B, Brice D (2007). Selected benthic faunas from the Devonian of the Ardennes: an estimation of palaeobiodiversity. Acta Geologica Polonica, $57: 223-262$

Jackson JBC, Hughes TP (1985) Adaptive strategies of coral-reef invertebrates. American Scientist 73:265-274

Jakubowicz M, Król J, Zapalski MK, Wrzołek T, Wolniewicz P, Berkowski B (2019) At the southern limits of the Devonian reef zone: Palaeoecology of the Aferdou el Mrakib reef (Givetian, eastern Anti-Atlas, Morocco). Geological Journal 54:10-38

Kaandorp JA (1999) Morphological analysis of growth forms of branching marine sessile organisms along environmental gradients. Mar Biol 134:295-306

Kahng SE, Hochberg EJ, Apprill A, Wagner D, Luck DG, Perez D, Bidigare RR (2012) Efficient light harvesting in deep-water zooxanthellate corals. Mar Ecol Prog Ser 455:65-77

Keith SA, Baird AH, Hobbs JPA, Woolsey ES, Hoey AS, Fadli N, Sanders NJ (2018) Synchronous behavioural shifts in reef fishes linked to mass coral bleaching. Nat Clim Chang 8:986-991

Kershaw S (1994) Classification and geological significance of biostromes. Facies 31: 81-91

Kershaw S, Munnecke A, Jarochowska E (2018) Understanding Palaeozoic stromatoporoid growth. Earth-Sci Rev 187:53-76

Kiessling W (2008) Sampling-standardized expansion and collapse of reef building in the Phanerozoic. Foss Rec 11:7-18

Klovan JE (1974) Development of Western Canadian Devonian reefs and comparison with Holocene analogues. Am Assoc Pet Geol Bull 58:787-799

Königshof P, Kershaw S (2006) Growth forms and palaeoenvironmental interpretation of stromatoporoids in a Middle Devonian reef, southern Morocco(west Sahara). Facies 52:299-306

Król JJ, Jakubowicz M, Zapalski MK, Berkowski B (2018) Massive tabulates in competition for space: A case study from Aferdou el Mrakib (Middle Devonian, Anti-Atlas, Morocco). Palaeogeogr Palaeoclimatol Palaeoecol 497:105-116

Lang SC, Fleming PJG, Jell JS, Zhen YY, Cook A (1990). The Devonian-Carboniferous intracratonic Burdekin Basin, north Queensland: I. Carbonate-siliciclastic facies of the Fanning River Group. Proceedings, Pacific Rim Congress 1990, 3:621-630

Larcombe P, Ridd PV, Prytz A, Wilson B (1995) Factors controlling suspended sediment on inner-shelf coral reefs, Townsville, Australia. Coral Reefs 14:163-171 
Lecompte M (1958) Les récifs paleozoiques en Belgique. Geol Rundsch 47:384-401

Leinfelder RR (2001) Jurassic reef ecosystems. In: Stanley Jr GD (ed) The history and sedimentology of ancient reef systems. Springer, Boston, MA, pp 251-309

Lewis SE, Wüst RA, Webster JM, Shields GA, Renema W, Lough JM, Jacobsen G (2012) Development of an inshore fringing coral reef using textural, compositional and stratigraphic data from Magnetic Island, Great Barrier Reef, Australia. Mar Geol 299:18-32

Madin JS, Anderson KD, Andreasen MH, et al. (2016) The Coral Trait Database, a curated database of trait information for coral species from the global oceans. Sci Data 3:160017

Madin JS, Baird AH, Bridge TCL, Connolly SR, Zawada KJA, Dornelas M (2018) Cumulative effects of cyclones and bleaching on coral cover and species richness at Lizard Island. Mar Ecol Prog Ser 604:263-268

May A (1993) Korallen aus dem Höheren Eifelium und Unteren Givetium (Devon) des Nordwestlichen Sauerlandes (Rheinisches Schiefergebirge). Teil 1: Tabulate Korallen. Palaeontographica, Abteilung A 227:87-224

McGhee Jr GR, Clapham ME, Sheehan PM, Bottjer DJ, Droser ML (2012) A new ecological-severity ranking of major Phanerozoic biodiversity crises. Palaeogeogr Palaeoclimatol Palaeoecol 370:260-270

Mistiaen B, Brice D, Zapalski MK, Loones C (2012) Brachiopods and their auloporid epibionts in the Devonian of Boulonnais (France): comparison with other associations globally. In: Talent J (ed), Earth and Life, Springer, Dordrecht, pp. 159-188

Morrissey J (1980) Community structure and zonation of microalgae and hermatypic corals on a fringing reef flat of Magnetic Island (Queensland, Australia). Aquat Bot 8:91-139

Playford PE (1980) Devonian "Great Barrier Reef" of Canning Basin, Western Australia. Am Assoc Pet Geol Bull 64:814-840

Porter JW (1976) Autotrophy, heterotrophy, and resource partitioning in Caribbean reef-building corals. Am Nat 110(975):731-742

Quattrini AM, Rodríguez E, Faircloth BC, Cowman PF, Brugler MR, Farfan GA, Hellberg ME, Kitahara MV, Morrison CL, PazGarcia DA, Reimer JD, McFadden CS (2020) Palaeoclimate ocean conditions shaped the evolution of corals and their skeletons through deep time. Nat Ecol Evo, https://doi.org/ https://doi.org/10.1038/s41559-020-01291-1

Racki G (1992) Evolution of the bank to reef complex in the Devonian of the Holy Cross Mountains. Acta Palaeontol Pol 37:87-182

Renema W (2019) Large benthic foraminifera in low-light environments. In Loya Y, Puglise KA, Bridge T (eds), Mesophotic Coral Ecosystems, Springer, Cham, pp. 553-561

Riegl B, Heine C, Branch GM (1996) Function of funnel-shaped coral growth in a high-sedimentation environment. Mar Ecol Prog Ser 145:87-93

Rogers CS (1990) Responses of coral reefs and reef organisms to sedimentation. Mar Ecol Prog Ser 62:185-202

Scoffin TP (1993) The geological effects of hurricanes on coral reefs and the interpretation of storm deposits. Coral Reefs 12:203-221

Scotese RC, Barrett SF (1990) Gondwana's movement over the South Pole during the Palaeozoic: evidence from lithological indicators of climate. Geological Society, London, Memoirs, 12:75-85

Scrutton CT (1997) The Palaeozoic corals, I: origins and relationships. Proceedings of the Yorkshire Geological Society 51:177-208

Scrutton CT (1998) The Palaeozoic corals, II: structure, variation and palaeoecology. Proceedings of the Yorkshire Geological Society, $52: 1-57$
Shen JW, Webb GE, Jell JS (2008) Platform margins, reef facies, and microbial carbonates; a comparison of Devonian reef complexes in the Canning Basin, Western Australia, and the Guilin region, South China. Earth-Sci Rev 88:33-59

Strathmann RR (1996) Biotic and abiotic factors regulating life cycles. 2.2. Adaptive strategies. Oceanologica Acta 19:309-311

Swinchatt JP (1969) Algal boring: a possible depth indicator in carbonate rocks and sediments. Geol Soc Am Bull 80:1391-1396

Talent JA, Mawson R (1994) Conodonts in relation to age and environmental framework of the Burdekin Basin (Mid-Devonian), north-eastern Australia. Courier Forschungsinstitut Senckenberg, 168:61-81

Todd PA (2008) Morphological plasticity in scleractinian corals. Biological Reviews, 83:315-337

Tsien HH, Mouravieff AN, Mountjoy EW (1980) Devonian reefs in Belgium. Geobios, Memoire special 4:17-33

Veron JEN (1995) Corals in space and time: the biogeography and evolution of the Scleractinia. Cornell University Press

Wood R (1999) Reef evolution. Oxford. Oxford University Press

Zapalski MK (2005) Paleoecology of Auloporida: an example from the Devonian of the Holy Cross Mts., Poland. Geobios, 38:677-683

Zapalski MK (2012) Tabulate corals from the Givetian and Frasnian of the southern region of the Holy Cross Mountains (Poland). Special Papers in Palaeontology 87:1-100

Zapalski MK (2014) Evidence of photosymbiosis in Palaeozoic tabulate corals. Proc $\mathrm{R}$ Soc Lond B Biol Sci, 281(1775):20132663

Zapalski MK, Berkowski B (2019) The Silurian mesophotic coral ecosystems: 430 million years of photosymbiosis. Coral Reefs 38:137-147

Zapalski MK, Hubert BL, Nicollin JP, Mistiaen B, Brice D (2007). The palaeobiodiversity of stromatoporoids, tabulates and brachiopods in the Devonian of the Ardennes-changes through time. Bulletin de la Société Géologique de France 178:383-390

Zapalski MK, Nowicki J, Jakubowicz M, Berkowski B (2017a) Tabulate corals across the Frasnian/Famennian boundary: architectural turnover and its possible relation to ancient photosymbiosis. Palaeogeogr Palaeoclimatol Palaeoecol 487:416-429

Zapalski MK, Wrzołek T, Skompski S, Berkowski B (2017b) Deep in shadows, deep in time: the oldest mesophotic coral ecosystems from the Devonian of the Holy Cross Mountains (Poland). Coral Reefs 36:847-860

Zatoń M, Borszcz T, Berkowski B, Rakociński M, Zapalski MK, Zhuravlev AV (2015) Paleoecology and sedimentary environment of the Late Devonian coral biostrome from the Central Devonian Field, Russia. Palaeogeogr Palaeoclimatol Palaeoecol 424:61-75

Zatoń M, Zapalski MK, Berkowski B, Wrzołek T (2018) Cryptic encrusting communities in a Middle Devonian mesophotic paleoenvironment of the Holy Cross Mountains, Poland. Palaeogeogr Palaeoclimatol Palaeoecol 501:82-91

Zhen YY (1991) Devonian rugose coral faunas and biostratigraphy of the Fanning River Group, north Queensland. University of Queensland, Ph. D. thesis. p 394+8+80

Zhen YY (1995) Late Emsian rugose corals of the Mount Podge area, Burdekin Basin, north Queensland. Alcheringa 19:193-234

Zhen YY (1996) Succession of coral associations during a Givetian transgressive-regressive cycle in Queensland. Acta Palaeontol Pol 41:59-88

Publisher's Note Springer Nature remains neutral with regard to jurisdictional claims in published maps and institutional affiliations. 